\title{
Cognition and Perception About Tooth Brush Maintenance and its Contamination
}

\author{
A. Vinita Mary ${ }^{1}$, R. Kesavan ${ }^{2}$, R. Hema Maheswari ${ }^{3 *}$, Jasti Keerthi ${ }^{4}$, S. Jenisha Priyavadhani ${ }^{5}$, \\ S. Fathima Zinnerah ${ }^{6}$ \\ ${ }^{1}$ Professor \& Head, Department of Public Health Dentistry, Thai Moogambigai Dental College and Hospital, \\ Chennai, India \\ ${ }^{2}$ Professor, Dept. of Public Health Dentistry, Thai Moogambigai Dental College and Hospital, Chennai, India \\ 3,4,5,6 Junior Resident, Department of Public Health Dentistry, Thai Moogambigai Dental College and Hospital, \\ Chennai, India \\ *Corresponding author: hemarkumar66@gmail.com
}

\begin{abstract}
Introduction: Good oral health is essential for everyone; it can be achieved by proper brushing. The continuous usage of tooth brush leads to contamination, so the disinfection of toothbrush plays an important role in maintenance of toothbrush.

Aim: This study was aimed to assess the knowledge, attitude and awareness about the toothbrush maintenance and its contamination among the general population in India.

Methodology: A cross sectional study was conducted using selfadministered questionnaire, through Google forms, due to pandemic situation, among 510 people from the age group of 20 60 years old in India. Statistics was done and tabulated.

Results: On knowledge about tooth brush maintenance, $83 \%$ of the participants agreed to the fact that usage of tooth brush is related to oral hygiene. In response to frequency of brushing $62 \%$ responded as they brush once a day. On concept of sharing toothbrush $91.8 \%$ responded that they don't share their tooth brush while $4.1 \%$ agreed to share their toothbrush. About $74 \%$ participants responded as bacteria is responsible for tooth brush contamination. Regarding to the usage of pre brushing mouthwash, $71.2 \%$ reported as they don't use it and remaining $28.8 \%$ were aware of using it.

Conclusion: Thus, awareness and knowledge level regarding toothbrush maintenance and its contamination among people was found to be low, which can be improved by community oral health programmes.
\end{abstract}

Keywords: Disinfection, Microorganism, Oral hygiene maintenance, Toothbrush.

\section{Introduction}

Good oral health is important for every individual to maintain good health [1]. Tooth brush plays a majorrole in achieving proper oral hygiene [2]. For that, knowledge about tooth brush such as usage, storage, and its contamination, and alternative for tooth brush should be known by each and every individual [3].

Toothbrushes may play a significant part in disease transmission and increase the risk of infection as they can serve as a reservoir for microorganisms in medically ill adults [2].

Proper brushing procedure should be known by every individual, as the pressure applied during brushing may cause irritation to the gingiva and affects the bone around the teeth thereby further leading to periodontal disease. Thus, proper handling of tooth brush also plays a vital role in maintaining oral hygiene.

The concept of toothbrush contamination after usage was give Cobb by early as 1920, who proposed that contaminated toothbrush as a cause for repeated infection of oral cavity [7].

Tooth brush becomes contaminated gradually after daily usage for long routine [2]. The contamination sources include the surrounding environment, microorganisms, storage containers and sharing of tooth brush. Also, the tooth brush bristles and its type of arrangement may pave the way for easy accumulation of debris and microorganisms [3].

Depending upon storage conditions, the toothbrush can, therefore, serve as a reservoir for their introduction of potential pathogens, such as Streptococcus mutans, Actinomyces, Porphyromonas species. Micro-organisms from storage environments can also be introduced; these include enteric bacteria dispersed via aerosols from toilet flushing, from contaminated fingers and skin commensals and pseudomonas emanating from the bathroom and other wet areas [8].

According to Devine et al. there is a requirement for disinfection methods for toothbrushes that are quickly effective, cost effective, nontoxic, and that can be easily performed [15].

Proper disinfecting procedures may lessen the chances of contamination [3].

Tooth brush can be disinfected in various methods such as disinfecting in alcohol-based solutions, antimicrobial solutions and chemical solutions like formaldehyde, hydrogen peroxide, glutaraldehyde, chlorhexidine etc. [1]. A contaminated tooth brush may cause gingivitis, dental caries, stomatitis and infections [11].

It is mandatory to decontaminate tooth brushes, in order to eliminate microorganism which are transmitted via used toothbrushes, from oral cavity, storage areas, or from other tooth brushes [13]. 


\section{IJRESM https://www.ijresm.com | ISSN (Online): 2581-5792 | RESAIM Publishing}

The goal of this study is to evaluate the awareness among general public about tooth brush maintenance and its sources of contamination.

\section{Methodology}

This study was designed to measure the self-perception, knowledge, and awareness about toothbrush maintenance and its contamination. A cross sectional study, was conducted among randomly selected people from age group of 20-60 years in India. A total of 510 participants were participated among them 142 were males, 368 were females. The participants were informed about the study and assured that their participation was purely voluntary. It was conducted in India from June 2020 to August 2020during COVID 19 pandemic lockdown period. The self-administered structured questionnaire consisted of 22 questions in English, which included demographic details, socio economic status and substantive questions exploring the respondents about toothbrush maintenance and its contamination. The questionnaire had a combination of selected response to the question and close ended questions (Yes/No). It took about 510 minutes to complete the questionnaires for the participants. The questions were converted into google forms and shared to the participants via social network. The purpose and aim of the study were explained with requesting for participation, to the participants. Subsequently responses were collected and data was analysed.

\section{Results}

Of 510 participants, from age group of 20 years to 60 years participated in this study, the mean age was $27.38+7.81$. Among them, 27.8\% were males $(\mathrm{n}=142)$ and $72.2 \%$ were females $(\mathrm{n}=368)$. Majority, 93.13\% participants were from Chennai, in Tamil Nadu. With regard to socioeconomic status, 55\% earned less than Rs. 25,000 per month.

About $83 \%$ of participants agreed that the usage of toothbrush was related to oral health. When asked about the frequency of brushing, $62 \%$ responded as they brushed once a day, $36.9 \%$ responded as twice or more than that. Regarding the efficiency of toothbrush, $72 \%$ said that 3 months was the normal efficiency of a toothbrush, whereas $21 \%$ responded as 5 months. On concept of sharing of toothbrush, $91.8 \%$ responded that they did not share toothbrush. About $74 \%$ responded as bacteria was responsible for toothbrush contamination. About pre-brushing mouthwash, $71.2 \%$ reported as they didn't use it and $28.8 \%$ used it. when asked about, the reason for not using any pre-brushing mouthwash, $48.4 \%$ did not give any reasons, $27.3 \%$ as did not used it before, $6.7 \%$ responded as due to harmful effects of mouthwash. About storage of toothbrush, $64.3 \%$ reported as using cap holder, $14.7 \%$ reported as storing outside the bathroom, $14.3 \%$ reported as storing inside the bathroom, $5.3 \%$ storing as upside down, $1.4 \%$ in water.

Table 1

Distribution of study participants according to demographic details

\begin{tabular}{|c|c|c|c|}
\hline QUESTION & OPTION & FREQUENCY & PERCENT \\
\hline \multirow[t]{2}{*}{ Gender } & Female & 368 & 72.2 \\
\hline & Male & 142 & 27.8 \\
\hline \multirow[t]{2}{*}{ Age } & $20-30$ & 382 & 74.9 \\
\hline & $31-60$ & 128 & 25.1 \\
\hline \multirow{5}{*}{ Area } & Village & 4 & 0.8 \\
\hline & Rural & 150 & 29.4 \\
\hline & semi urban & 104 & 20.4 \\
\hline & Town & 4 & 0.8 \\
\hline & Urban & 248 & 48.6 \\
\hline \multirow{14}{*}{ Occupation } & Student & 73 & 14.3 \\
\hline & Agriculture & 2 & .4 \\
\hline & Business & 3 & .6 \\
\hline & Clerks & 12 & 2.4 \\
\hline & Crafts-related workers & 19 & 3.7 \\
\hline & Entrepreneur & 1 & .2 \\
\hline & House wife & 1 & .2 \\
\hline & Professionals & 222 & 43.5 \\
\hline & Skilled workers & 22 & 4.3 \\
\hline & Tailoring & 1 & .2 \\
\hline & Teacher & 1 & .2 \\
\hline & Technical Associate & 1 & .2 \\
\hline & $\begin{array}{l}\text { Technicians \& } \\
\text { associate } \\
\text { professionals }\end{array}$ & 79 & 15.5 \\
\hline & Unemployed & 73 & 14.3 \\
\hline \multirow{7}{*}{$\begin{array}{l}\text { Educational } \\
\text { Qualification }\end{array}$} & Arts \& science & 136 & 26.7 \\
\hline & Dental & 97 & 19.0 \\
\hline & $\begin{array}{l}\text { Engineering\& } \\
\text { technology }\end{array}$ & 174 & 34.1 \\
\hline & Medical & 36 & 7.1 \\
\hline & Nursing & 12 & 2.4 \\
\hline & Others & 46 & 9.0 \\
\hline & school students & 9 & 1.8 \\
\hline \multirow{5}{*}{$\begin{array}{l}\text { Monthly } \\
\text { Income }\end{array}$} & $<25,000$ & 280 & 54.9 \\
\hline & $>1,00,000$ & 29 & 5.7 \\
\hline & $25,000-50,000$ & 111 & 21.8 \\
\hline & $50,000-75,000$ & 61 & 12.0 \\
\hline & $75,000-1,00,000$ & 29 & 5.7 \\
\hline
\end{tabular}

Table 2

Distribution of study participants according to cognition and perception about tooth brush maintenance \& its contamination

\begin{tabular}{|l|l|l|l|}
\hline \multicolumn{1}{|c|}{ QUESTION } & \multicolumn{1}{|c|}{ OPTION } & FREQUENCY & \multicolumn{1}{c|}{ PERCENT } \\
\hline Do you think the use of toothbrush is directly related to your Oral health? & Yes & 424 & 83.1 \\
\cline { 2 - 4 } & No & 18 & 3.5 \\
\cline { 2 - 4 } & May be & 68 & 13.3 \\
\hline How often do you brush? & Once a day & 322 & 63.2 \\
\cline { 2 - 4 } & Twice or more a day & 188 & 225 \\
\hline How long do you brush? & $1-2$ min & 231 \\
\cline { 2 - 4 } & $2-3$ min & 44.8 & 45.3 \\
\cline { 2 - 4 } & more than 3 min & 54 \\
\hline
\end{tabular}


Volume-3, Issue-10, October-2020

https://www.ijresm.com | ISSN (Online): 2581-5792 | RESAIM Publishing

\begin{tabular}{|c|c|c|c|}
\hline \multirow[t]{4}{*}{ What type of toothbrush do you use? } & Extra hard & 3 & 0.6 \\
\hline & Hard & 29 & 5.7 \\
\hline & Medium & 305 & 59.8 \\
\hline & Soft & 173 & 33.9 \\
\hline \multirow[t]{3}{*}{ Do you think is it necessary to change your toothbrush at regular interval? } & Yes & 424 & 83.1 \\
\hline & No & 34 & 6.7 \\
\hline & May be & 52 & 10.2 \\
\hline \multirow[t]{5}{*}{ How often do you change your toothbrush? } & Within 2 weeks & 30 & 5.9 \\
\hline & Within 1 month & 73 & 14.3 \\
\hline & 2-3 months & 279 & 54.7 \\
\hline & 4-5 months & 95 & 18.6 \\
\hline & More than 5months & 33 & 6.5 \\
\hline \multirow[t]{5}{*}{ According to you what is the indicator of changing toothbrush? } & Bent & 86 & 16.9 \\
\hline & fading of colour of bristles & 46 & 9.0 \\
\hline & frayed bristles & 110 & 21.6 \\
\hline & All the above & 244 & 47.8 \\
\hline & None & 24 & 4.7 \\
\hline \multirow[t]{3}{*}{ What is the normal efficiency of toothbrush to clean teeth? } & 3 months & 368 & 72.2 \\
\hline & 5 months & 107 & 21.0 \\
\hline & More than 5months & 35 & 6.9 \\
\hline \multirow[t]{4}{*}{ What factors affect the toothbrush efficiency? } & Brushing technique & 70 & 13.7 \\
\hline & Duration & 66 & 12.9 \\
\hline & Pressure & 102 & 20.0 \\
\hline & All the above & 272 & 53.4 \\
\hline \multirow[t]{2}{*}{ Do you use any pre brushing mouthwashes? } & Yes & 147 & 28.8 \\
\hline & No & 363 & 71.2 \\
\hline \multirow[t]{3}{*}{ Is it okay to share your toothbrush? } & Yes & 21 & 4.1 \\
\hline & No & 468 & 91.8 \\
\hline & May be & 21 & 4.1 \\
\hline \multirow[t]{3}{*}{ Does brushing for longer duration causes the bristles to fray? } & yes & 232 & 45.5 \\
\hline & No & 79 & 15.5 \\
\hline & May be & 199 & 39.0 \\
\hline \multirow[t]{3}{*}{ Can old toothbrush cause sore throat? } & Yes & 140 & 27.5 \\
\hline & No & 85 & 16.7 \\
\hline & May be & 285 & 55.9 \\
\hline \multirow[t]{5}{*}{ what are the ways that toothbrush and tooth paste can transmit the infections? } & Sharing the toothbrush & 212 & 41.6 \\
\hline & Sharing the toothpaste & 15 & 2.9 \\
\hline & $\begin{array}{l}\text { Uncleaned toothbrush too leads infections, hygiene is } \\
\text { important }\end{array}$ & 1 & 0.2 \\
\hline & Using old toothbrush & 89 & 17.5 \\
\hline & All the above & 193 & 37.8 \\
\hline \multirow[t]{4}{*}{ What is the microorganism responsible for contamination of toothbrush? } & Bacteria & 381 & 74.7 \\
\hline & Fungi & 95 & 18.6 \\
\hline & Virus & 32 & 6.3 \\
\hline & None & 2 & 0.4 \\
\hline \multirow[t]{6}{*}{ What is the source of toothbrush contamination? } & External environment & 217 & 42.5 \\
\hline & Oral cavity & 165 & 32.4 \\
\hline & Contact with another toothbrush & 125 & 24.5 \\
\hline & Not proper maintenance of toothbrush & 1 & 0.2 \\
\hline & Not washing it property & 1 & 0.2 \\
\hline & Don't know & 1 & 0.2 \\
\hline \multirow[t]{8}{*}{ What is the best method to store the toothbrush? } & Placing it in a cap holder & 252 & 49.4 \\
\hline & Placing it in a bathroom & 35 & 6.9 \\
\hline & Placing it in chlorhexidine solution & 14 & 2.7 \\
\hline & placing it in upright position & 22 & 4.3 \\
\hline & Placing it in water & 18 & 3.5 \\
\hline & Placing it upside down & 26 & 5.1 \\
\hline & placing outside the bathroom & 38 & 7.5 \\
\hline & All the above & 105 & 20.6 \\
\hline \multirow[t]{3}{*}{ Does keeping toothbrush in boiling water kill bacteria? } & Yes & 202 & 39.6 \\
\hline & No & 76 & 14.9 \\
\hline & May be & 232 & 45.5 \\
\hline Does disinfecting the toothbrush play an important role in breaking the & Yes & 239 & 46.9 \\
\hline transmission of infection? & No & 38 & 7.5 \\
\hline & May be & 233 & 45.7 \\
\hline
\end{tabular}




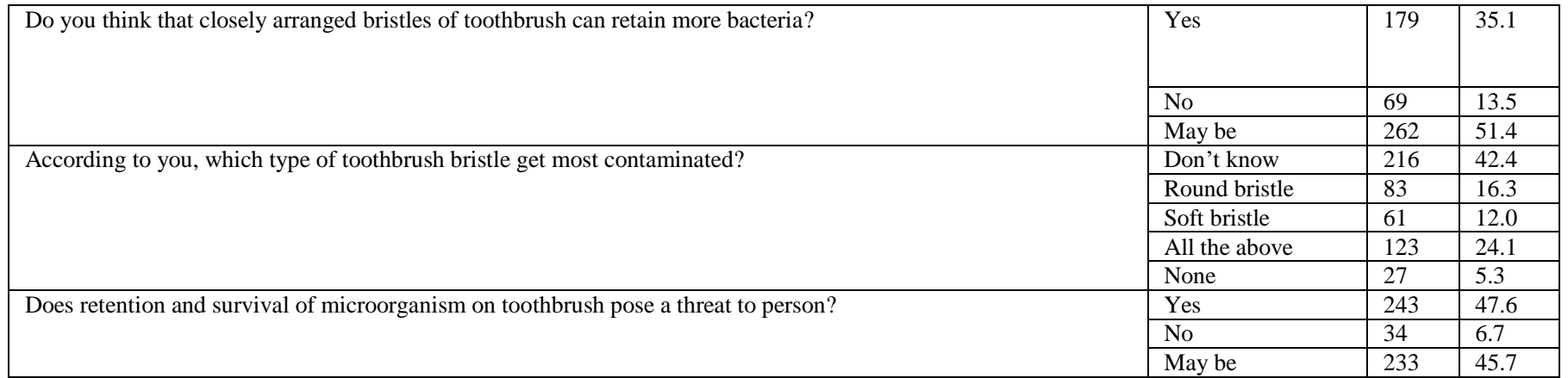

\section{Discussion}

This study was about assessment of knowledge, attitude and awareness about toothbrush maintenance and its contamination among general public in India.

The knowledge on oral health care aids in preventing systemic and oral diseases. Toothbrush plays an important role in maintaining oral hygiene. The toothbrushes are varying in size, shape, texture, and design more than any other category of dental products. They are also available in different sizes large, medium, and small to adapt better to the oral cavity of different individuals. It consists of head with bristles and handle. The bristles are bunched together; they are known as tufts [9].

The tufts in the toothbrush is mostly prone to heavy contamination. Thus, it may lead to split due to regular usage without proper disinfection, which leads to more contamination [3]. Toothbrush may be contaminated from both outside and inside environmental factors such as oral microbes, saliva, and debris [2]. So thus, disinfection of toothbrush, maintenance of it plays a major role in oral hygiene maintenance

Every individual was rather consistent in the degree of wear they induce during brushing. The level of wear appeared to be more important. Variation in the degree of wear is most likely caused by differing tooth brushing forces and techniques amongst individuals [10].

In this study, 83\% participated reported as yes in regarding to the question of toothbrush is directly related to maintaining the oral hygiene, which ultimately shows that people believe in tooth brushing than any other practice in maintaining their oral hygiene.

About $63.2 \%$ participants reported as once in regarding to frequency of brushing in a day, whereas $36.8 \%$ reported as twice or more. In comparison to the study [1] by Keerthana Ravikumar et al, brushing frequency twice option was higher than the present study which might be because people were not so interested in brushing more than once a day. The dental fraternity should motivate the patients to brush twice a day as a routine in their daily lifestyle.

With regard to microorganism responsible for contamination of toothbrush, $74.7 \%$ stated as bacteria, $18.6 \%$ stated as fungi $6.3 \%$ stated as virus, which is similar to the study [3] by Sowmya KR et al, thus, results show that people were aware that the microorganisms contaminate toothbrush.

Microorganism has the potential to stay viable up to a week's even after brushing. Contaminated tooth brushes have a major impact in many oral and systemic disease such as septicaemia, Gastrointestinal, cardiovascular, renal problems [12].

In regard to best method for storage of toothbrush, $49.4 \%$ participants stated as placing toothbrush with cap holder, $7.5 \%$ participants reported as placing toothbrush outside the bathroom, 6.9\% participants reported as placing inside the bathroom, $5.1 \%$ participants stated as placing toothbrush in upside down, $4.3 \%$ participants as placing toothbrush in a upright position, $2.7 \%$ participants reported as placing it in a chlorhexidine solution, remaining $20.6 \%$ participants as above all the methods as best method of storage. When compared to the study [5] by Kumar G et al, knowledge in this study was higher regarding the storage but still remaining people must be educated regarding the storing of toothbrush.

In regard to cause for contamination of toothbrush, $42.5 \%$ participants reported as external environment, $24 \%$ participants stated as contacting with other toothbrush, $32.5 \%$ participants reported as oral cavity, $0.2 \%$ participants reported as not maintaining it properly, hence, the knowledge of our study participants was less satisfactory when compared to the study [3] by Sowmya KR et al.

In this study, $46.9 \%$ participants agreed that disinfection played an important role in breaking the transmission of infection through tooth brush. Awareness programs and campaigns need to be conducted to increase the awareness, and knowledge about disinfection of toothbrush.

Oral health is an inherent part of general health, it either directly or indirectly reflects the entire wellbeing of an individual, therefore maintenance of good oral hygiene is a pivotal factor [14].

\section{Conclusion}

There is difference regarding the knowledge, attitude and awareness about toothbrush maintenance and its contamination among people, which should be increased by conducting more oral health awareness programmes, campaigns and researches to improve the awareness among the people.

\section{References}

[1] Kumar KR and Ravindran V. Knowledge and behaviour of undergraduate students in a dental school regarding tooth brush disinfection. Drug invention today 12(10): 2157-59. 
[2] Frazelle MR and Munro CL. Toothbrush contamination: a review of the literature. Nurs Res Pract. 2012; 2012:420630.

[3] Sowmya KR, Puranik MP, James JM and Sabbarwal B. Perceptions about toothbrush contamination and disinfection among dental students in Bengaluru City: A cross-sectional study. Indian J Dent Res. 2017 NovDec;28(6):646-649.

[4] Vyas M and Vyas S. Oral hygiene practices, Beliefs and Knowledge towards Dental Care. International Journal of Contemporary Medical Research 2018:5(2):B11-B13.

[5] Kumar G, Sethi AK, Tripathi RM, Pratik and Barman D. Assessment of Knowledge, Attitude, and Practice of Dental and Medical Interns toward Toothbrush Maintenance and Replacement in Bhubaneswar City, Odisha, India. J Pharm Bio Allied Sci. 2018 Apr-Jun;10(2):77-82.

[6] Madan Kumar PD, Sequeira PS and Peter S. Dental Interns Attitudes Toward Toothbrush Replacement and Maintenance. Journal of the Indian Association of Public Health Dentistry, Vol. 2005, Issue 6.

[7] Mehta A, Sequeira PS and Bhat G. "Bacterial contamination and decontamination of toothbrushes after use," The New York State Dental Journal, vol. 73, no. 3, pp. 20-22, 2007.

[8] Taji SS and Rogers AH. "The microbial contamination of toothbrushes. A pilot study,” Australian Dental Journal, vol. 43, no. 2, pp. 128-130, 1998.

[9] Baruah K, Thumpala VK, Khetani P, Baruah Q, Tiwari RVC and Dixit H. A Review on Toothbrushes and Tooth Brushing Methods. International
Journal of Pharmaceutical Science Invention, Volume 6, Issue 5, pp. 2938, May 2017.

[10] Van Leeuwen MPC, Van der Weijden FA, Slot DE and Rosema MAM. Toothbrush wear in relation to tooth brushing effectiveness. Int. J Dent Hyg. 2019 Feb;17(1):77-84.

[11] Naik R, Ahmed Mujib BR, Telagi N, Anil BS and Spoorthi BR. Contaminated tooth brushes-potential threat to oral and general health. J Family Med Prim Care. 2015 Jul-Sep;4(3):444-8.

[12] Basman, Adil and Peker, Ilkay and Akca, Gulcin and Alkurt T, Meryem and Sarikir, Cigdem and Celik and Irem. 2015 Evaluation of toothbrush disinfection via different methods. Brazilian oral research. 30 .

[13] Sheikh, N and Rajhans, N and Mhaske, N and Moolya, N and Sudip HM. 2014 Toothbrush disinfection -A myth or reality? A comparative evaluation of $4 \%$ disodium EDTA, $10 \%$ sodium perborate in the disinfection of tooth brushes: clinic microbiological study. International Journal of Medical Research \& Health Sciences. 3. 840.

[14] Karibasappa GN, Narayan L, Nagesh and Sujatha BK. 2011 Assessment of microbial contamination of toothbrush head: An in vitro study. Indian journal of dental research: official publication of Indian Society for Dental Research. 22. 2-5.

[15] Devine DA, Percival RS, Wood DJ, Tuthill TJ, Kite P and Killington RA et al. Inhibition of biofilms associated with dentures and toothbrushes by tetrasodium EDTA. J Appl. Microbiol. 2007 Dec;103(6):2516-24. 